\title{
The Spatial Variation of Mugil cephalus in the Negombo Estuary in Relation to Physico-chemical Parameters
}

\author{
B. R. C. Mendis ${ }^{1}$, M. M. M. Najim ${ }^{2}$, H. M. P. Kithsiri ${ }^{3}$ and Lahiru \\ Udayangana $^{4}$ \\ ${ }^{1} \mathrm{PhD}$ Student, Faculty of Graduate Studies, University of Colombo \\ ${ }^{2}$ Vice Chancellor, South Eastern University of Sri Lanka \\ ${ }^{3}$ Deputy Director General (Research and Development) National Aquatic Resources \\ Research and Development Agency \\ ${ }^{4}$ Lecturer, Department of Agriculture, University of Wayamba
}

\begin{abstract}
Analysis of physico - chemical parameters gives an insight to the spatial distribution of Mugil cephalus in Negombo estuary. The present study was carried out to the spatial distribution of Mugil cephalus that is governed by the physico - chemical parameters in bottom overlying surface water in Negombo estuary, Sri Lanka. Samplings at selected sites were done during one year study period from January 2017 to December 2017. During this study, fish (Mugil cephalus) and water samples were collected at Sea mouth, Duwa, Pitipana, Munnakkaraya, Dungalpitya, Dandugam Oya and Katunayake sites. Physico - chemical parameters such as the water temperature, salinity, $\mathrm{pH}, \mathrm{DO}$, electrical conductivity, BOD, COD and nutrients levels in the bottom overlying water were measured and analyzed using employing standards methods. The results revealed that salinity, $\mathrm{pH}, \mathrm{EC}$, BOD and nutrient levels were below the maximum permissible limits of the discharge industrial wastewater quality standards of the Central Environmental Authority (CEA), Sri Lanka. The COD levels were higher than the permissible threshold limits. The seasonality in the physico - chemical levels of water were observed with a peak period from May/June and October/November, which apparently coincided with the inter monsoonal periods of the island.
\end{abstract}

Key words: Mugil cephalus, Negombo estuary, Physico - chemical parameters, Spatial variation of Mugil cephalus 


\section{Introduction}

Estuaries are transitional environments between rivers and the sea, and are characterized by widely varying, localized and often unpredictable adverse hydrological and physico - chemical environmental conditions (Day et al. 1989). The grey mullet (Mugil cephalus) is an important edible fish catch constituent in the Negombo estuary.

Various types of detailed investigations into the biology, ecology and fishery of grey mullet in Negombo estuary have been conducted by Wijayaratne and Costa (1987). According to the literature, water pollution is a serious environmental problem in the Negombo estuary. It is the degradation of the quality of water that renders water unsuitable for its intended purposes. Contamination of aquatic ecosystems with a wide range of pollutants has become a matter of concern over the past few decades (Narayan and Vinodhini, 2008). Effluents are directly discharged to the waterways and finally it ends up in the coast. Therefore, coastal habitats are highly vulnerable to degradation. These destructed habitats have directly or indirectly negative impact on the marine biodiversity and finally threat to the well-being of human. Therefore, pollution prevention is an important factor for the utilization and management of these resources and it is essential to determine the pollution of water quality. The present study, therefore, was carried out with a view to investigate how the spatial distribution of gray mullet in a tropical estuary in Sri Lanka is governed by localized physico chemical variations within the estuary. In this study, the variation of the Mugil sp. structure was determined in relation to some physico - chemical variables in the sediment and overlying water. This study also aimed at to identify the key physico - chemical parameters that govern the spatial variation of this economically valuable fish in the estuary.

\section{Research Methodology}

\section{Study site}

This study was carried out at the Negombo estuary (Figure 1) during the dry and wet season of the year 2017. Negombo estuary is situated on the west coast of Sri Lanka (latitude $7^{\prime}-7^{\circ} 12^{\prime} \mathrm{N}$ and longitude $79^{\circ}-79^{\circ} 53^{\prime} \mathrm{E}$ ). It is a shallow, well mixed basin type estuary, approximately $12 \mathrm{~km}$ in length, $3.5 \mathrm{~km}$ in width and has a mean depth of about $1.2 \mathrm{~m}$ (Hettiarachchi \& 


\section{Relation to Physico-chemical Parameters}

Samarawickrama, 2003) and receives freshwater mainly from Dandugam Oya, a river that is discharged to its southern end. The estuary opens to the sea by a single narrow opening in Negombo at its Northwestern end. Seven study sites namely Sea mouth, Duwa, Pitipana, Munnakkaraya, Dungalpitya, Dandugam Oya and Katunayake (Figure 1), representing of the mouth, canals segment as north, south, east and west region margin of the estuary were selected for the present study.

Figure 1: Selected sampling locations in Negombo estuary

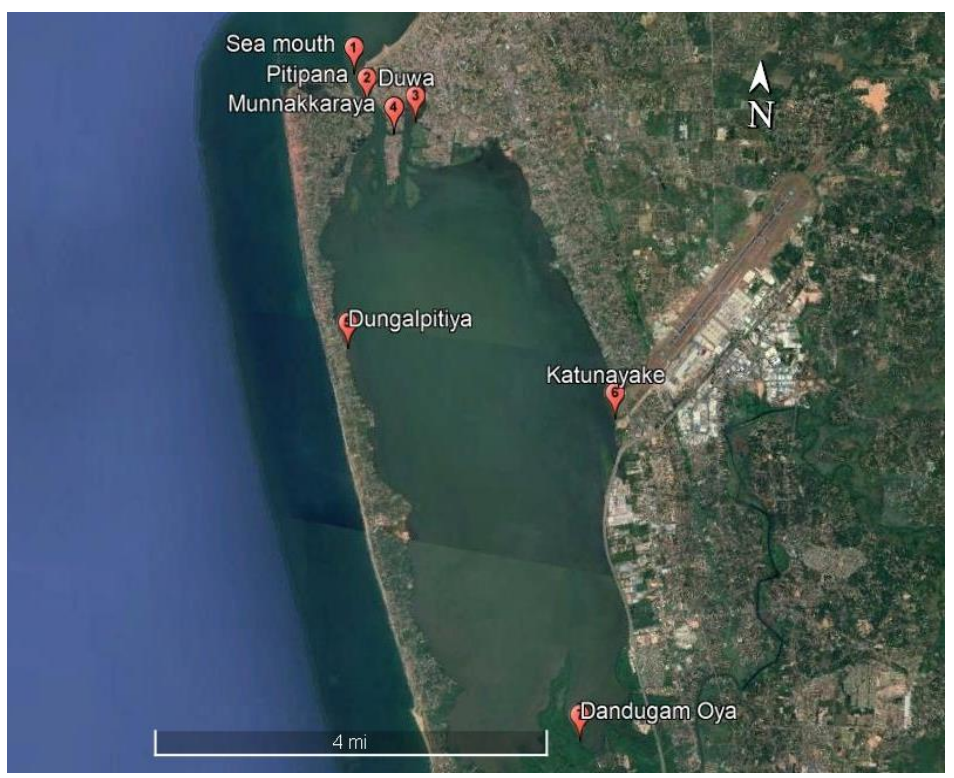

The Grey mullets (Family: Mugilidae) are widely distributed in the coastal waters, estuaries and even in freshwater in the tropical and subtropical regions of the world (Wijeyaratne and Costa, 1987). The mullets have been identified as an important group of fish in the subsistence fisheries in the coastal lagoons of Sri Lanka. Fifteen species of grey mullets have been recorded in estuaries in Sri Lanka (Wijeyaratne and Costa, 1987). The grey mullets have also been described as plankton feeders, herbivores, omnivores, slime feeders, bottom feeders, etc. In estuarine waters, grey mullet (Mugil cephalus) mainly feeds on detritus, diatoms, algae and microscopic invertebrates (McDonough and Wenner, 2003). 


\section{Water sample}

Water samples were collected from each sites into $(n=7)$ using $1 \mathrm{~L}$ polyethylene bottles with screw caps. Bottles were prepared by treating them with nitric acid and rinsed with distilled water before the samples were collected. The bottles were rinsed three times with the estuary water at the time of sampling. Samples were then collected by direct immersion of the sampling bottle into the estuary. The samples collected were placed in a polyethylene bottle, refrigerated and transferred cold to the laboratory for analysis. An ice box at $0{ }^{\circ} \mathrm{C}$ was used to transport the samples. Water sampling, storage, transportation and chemical analysis were carried out in accordance with Standard Methods for Examination of Water and Wastewater as given by American Public Health Association (APHA) (American Public Health Association, 2012). The principles and methods used in this study are given in Table 1 .

Table 1: Methods of water quality analysis

\begin{tabular}{|c|c|c|}
\hline Parameter & Principle & Method \\
\hline Water temperature & Thermometric & $\begin{array}{l}\text { Glass - Mercury Thermometer in }{ }^{\circ} \mathrm{C} \\
\text { (APHA, 2012) }\end{array}$ \\
\hline Dissolve Oxygen & Dissolve Oxygen & Orion $260 \mathrm{~A}$, potable DO meter \\
\hline Salinity & Refractive index & Refracto meter \\
\hline Electrical Conductivity & $\begin{array}{l}\text { Electrical } \\
\text { conductometric }\end{array}$ & $\begin{array}{l}\text { Hanna portable multi range } \\
\text { Conductivity meter HI - } 8733\end{array}$ \\
\hline $\mathrm{pH}$ & Potentiometric & Orion $260 \mathrm{~A}$, portable $\mathrm{pH}$ meter \\
\hline Ammoniacal - nitrogen & Spectrophotometric & $\begin{array}{l}4500 \mathrm{NH}_{3}-\mathrm{F} \text {, Phenate method } \\
\text { (APHA, 2012) }\end{array}$ \\
\hline Nitrate - nitrogen & Spectrophotometric & $\begin{array}{l}4500 \mathrm{E}-\mathrm{Cu} / \mathrm{Cd} \text { Reduction method } \\
\text { (APHA, 2012) }\end{array}$ \\
\hline Nitrite - nitrogen & Spectrophotometric & $\begin{array}{l}4500 \text { - F Colourmetric method } \\
\text { NED/Sulphanilamide(APHA, 2012) }\end{array}$ \\
\hline Orthophosphate & Spectrophotometric & $\begin{array}{l}4500 \text { P - E, Ascorbic acid (APHA, } \\
\text { 2012) }\end{array}$ \\
\hline $\begin{array}{l}\text { Biochemical oxygen } \\
\text { demand }\end{array}$ & Manometric & Aqua Lytic BOD sensors \\
\hline $\begin{array}{l}\text { Chemical oxygen } \\
\text { demand }\end{array}$ & Titrimetric & $\begin{array}{l}5220 \text { Open reflux method (APHA, } \\
\text { 2012) }\end{array}$ \\
\hline
\end{tabular}

Sources: (APHA, 2012) 


\section{Data analysis}

Differences in the levels of each physico - chemical parameters from the estuary were tested by one way analysis of variance (ANOVA). Significance was tested at the $p<0.05$ levels.

\section{Results}

The results of the physico - chemical parameters of the bottom overlying surface water, at seven sampling sites during the study period are tabulated in Table 2, along with the statistical analysis of variance (One - way ANOVA) of each parameter. Most of the physico - chemical parameters indicated a significant spatial variation between the sampling sites $(\mathrm{p}<0.05$, at 95\% level of significance), except for Electrical Conductivity (EC), $\mathrm{pH}$, Ammoniacal - nitrogen, Nitrite - nitrogen and Orthophosphate $(p>0.05)$ in accordance with the results of One - way ANOVA. Physico - chemical quality assessment of surface water bodies may widely reflect the pollution load, anthropogenic pressure and site specific characteristics. The sampling sites have many sites specific characteristics. Location of the site and depth at the sites are two important characters that influence physico - chemical characteristics of water. Monthly variations of average physico - chemical parameters in the sampling sites and mean monthly rainfall in the sites are graphically shown in Figure 2.

Throughout the study period, the lowest monthly water temperature $(29.50 \pm$ $0.40^{\circ} \mathrm{C}$ ) was recorded from site 7 (Dandugam Oya), while the highest value $\left(30.7 \pm 0.19^{\circ} \mathrm{C}\right.$ ) was observed at site 3 (Duwa) as shown in Table 2. One way analysis of variance (ANOVA) showed a significant difference in surface water temperature between sites $(p<0.05)$. Tukey's HSD test for separation of means revealed that mean water temperature varied significantly from mean water temperature observed at sites 1 to 5 and site 6 (Table 2).

According to these parameters, highest value of Dissolved Oxygen (DO) was recorded at site $3\left(10.8 \pm 2.80 \mathrm{mgL}^{-1}\right)$ while site 7 (Dandugam Oya) denoted the minimum concentration of $3.90 \pm 1.10 \mathrm{mgL}^{-1}$. The temporal variations of DO levels at the sampling sites revealed that the highest average DO levels 
are notable in June, while February accounts for the lowest DO concentrations (Figure 2a). The $\mathrm{pH}$ values of the seven sampling sites showed a wide fluctuation, ranging from $7.20 \pm 0.22$ to $8.30 \pm 0.36$ (Table 2). The $\mathrm{pH}$ values of the estuarine water at all the sites remained slightly alkaline (Figure 2b) whereby site 7 (Dandugam Oya) reported the lowest mean value of $7.20 \pm 0.22$. On the other hand, the highest $\mathrm{pH}$ value $(8.30 \pm$ 0.36) was recorded at the site 4 (Munnakkaraya) as indicated in Table 2 (Figure $2 \mathrm{~b}$ ). The $\mathrm{pH}$ values observed at all the sampling sites ranged (7.20 \pm 0.22 to $8.30 \pm 0.36)$ within the standard limits $(5.5-9.0)$ as recommended permissible threshold limits for the discharge of industrial wastewater standards by the Central Environmental Authrotity (CEA, 2007). The highest average EC value of $28.7 \pm 6.3 \mathrm{mScm}^{-1}$ at the site 04 (Munnakkaraya) was recorded while the lowest mean value $\left(17.86 \pm 4.3 \mathrm{mScm}^{-1}\right)$ was recorded at the site 06 (Table 2 and Figure 2c). The highest EC values were recorded in January, February and April (in the dry season), while the lowest values were recorded in May and October during the rainy season (Figure 2c).

Spatially, the highest salinity values were at site 4 (Munnakkaraya) and sites 3 (Duwa) followed by site 2 (Pitipana) and site 1 (Sea mouth) with average salinities of $24.72 \pm 3.21,23.6 \pm 2.4,23.1 \pm 2.80$ and $15.4 \pm 1.20$, respectively (Figure 2d). Meanwhile, with an average salinity of $1.4 \pm 0.30$ ppt, site 7 denoted the lowest salinity among the sampling sites (Table 2 and Figure 2d). The results indicated that the levels of salinity are comparatively low in sites 5 (Dungalpitiya), and 7 (Dandugam Oya), that are located in the West and South regions of the estuary (Table 2 and Figure 2d). This may be attributed to the dilution effect caused by the high freshwater discharge in the downstream of Dandugam Oya and Ja - ela canal entering from the Southern region of the estuary.

During the study period, Biochemical Oxygen Demand (BOD) varied in between $13.7 \pm 0.85$ to $29.8 \pm 3.7 \mathrm{mgL}^{-1}$ (Table 2). Maximum value of BOD was recorded at site 07 (Dandugam Oya) and the minimum was observed at site 1 (Sea mouth). The highest level of BOD was recorded during month of February (Figure 2e). In case of Chemical Oxygen Demand (COD), site 03 (Duwa) showed the highest value of $510.0 \pm 315.0 \mathrm{mgL}^{-1}$, symbolizing the presence of a high pollution load within the estuarine water (Table 2). High levels of COD recorded in this area may be partly due to the discharge of 
effluents from boat repair stations. The highest level of COD was recorded during the months of March and November. The lowest level was recorded during the month of December (Figure 2f). BOD values at site 7 (Dandugam Oya) and COD at site 03 were higher than the permissible threshold limits for the discharge of industrial wastewater standards of CEA (2007).

The highest value of Nitrate - nitrogen $\left(1.03 \pm 0.68 \mathrm{mgL}^{-1}\right)$ was noted at site 01 (Sea mouth), while the lowest $(0.26 \pm 0.06)$ was reported at site 4 (Figure $2 \mathrm{~g}$ ). Based on the temporal variations, the highest level of Nitrate - nitrogen was recorded during month of April (Table 2 and Figure 2g). Highest concentration of Nitrite - nitrogen $\left(0.48 \pm 0.04 \mathrm{mgL}^{-1}\right)$ recorded at site 06 (Figure $2 \mathrm{~g}$ ). The ammoniacal - nitrogen concentration varied from $0.31 \pm 0.1$ $\mathrm{mgL}^{-1}$ (site 6) to $0.43 \pm 0.20 \mathrm{mgL}^{-1}$ during (Site 3 ) the study period. Highest concentration of Orthophosphate $\left(0.52 \pm 0.03 \mathrm{mgL}^{-1}\right)$ recorded at site 03 (Figure 2g). Orthophosphate concentration also showed similar variations across the sampling sites within the Negombo estuary. It was interesting to note the nutrient concentrations at all sampling sites were within the permissible threshold limits for the discharge of industrial wastewater standards of CEA (2007). 
Table 2: Physico - chemical parameters of water (Mean \pm SE) of the eight sampling sites at the Negombo estuary

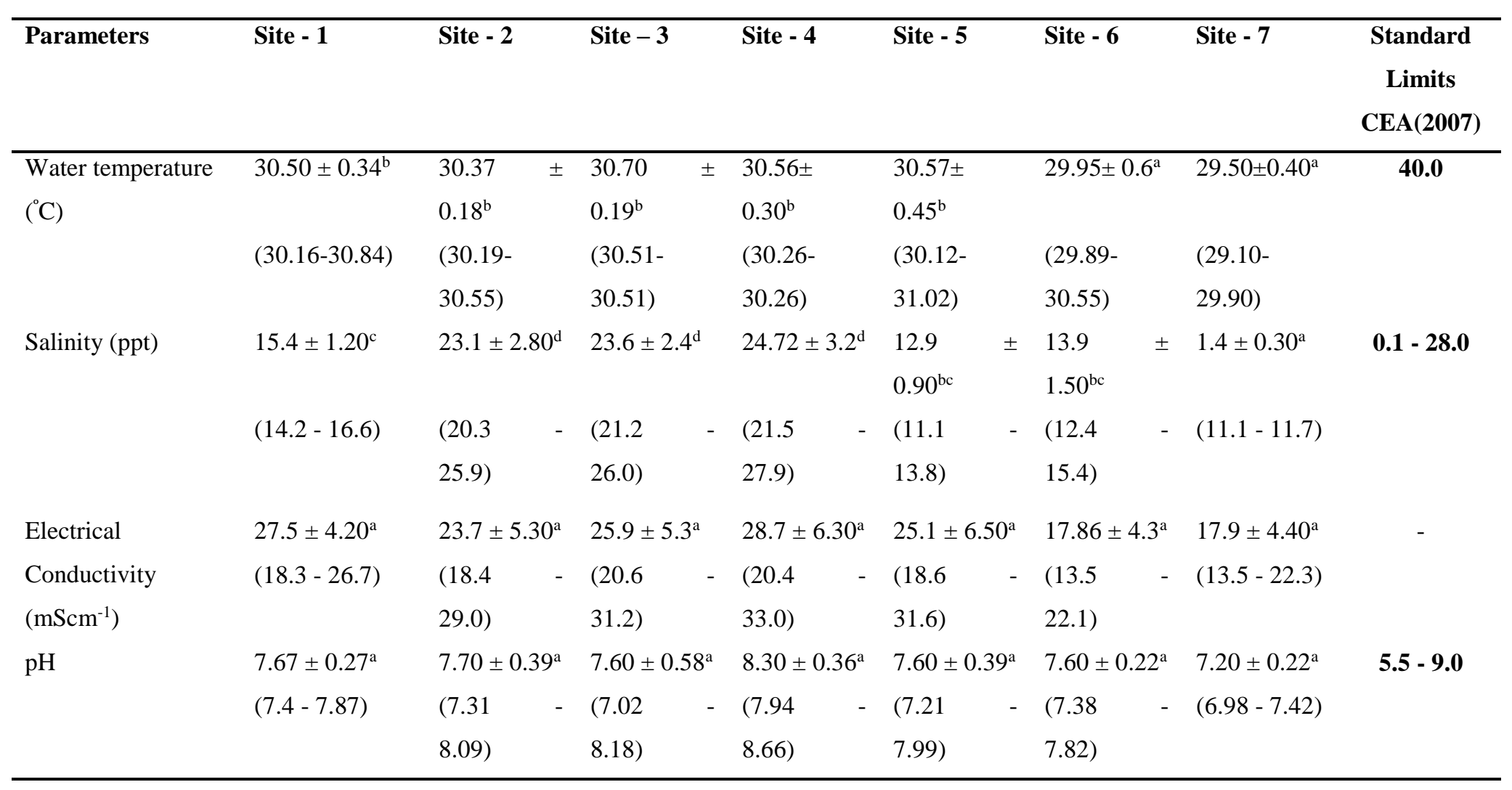




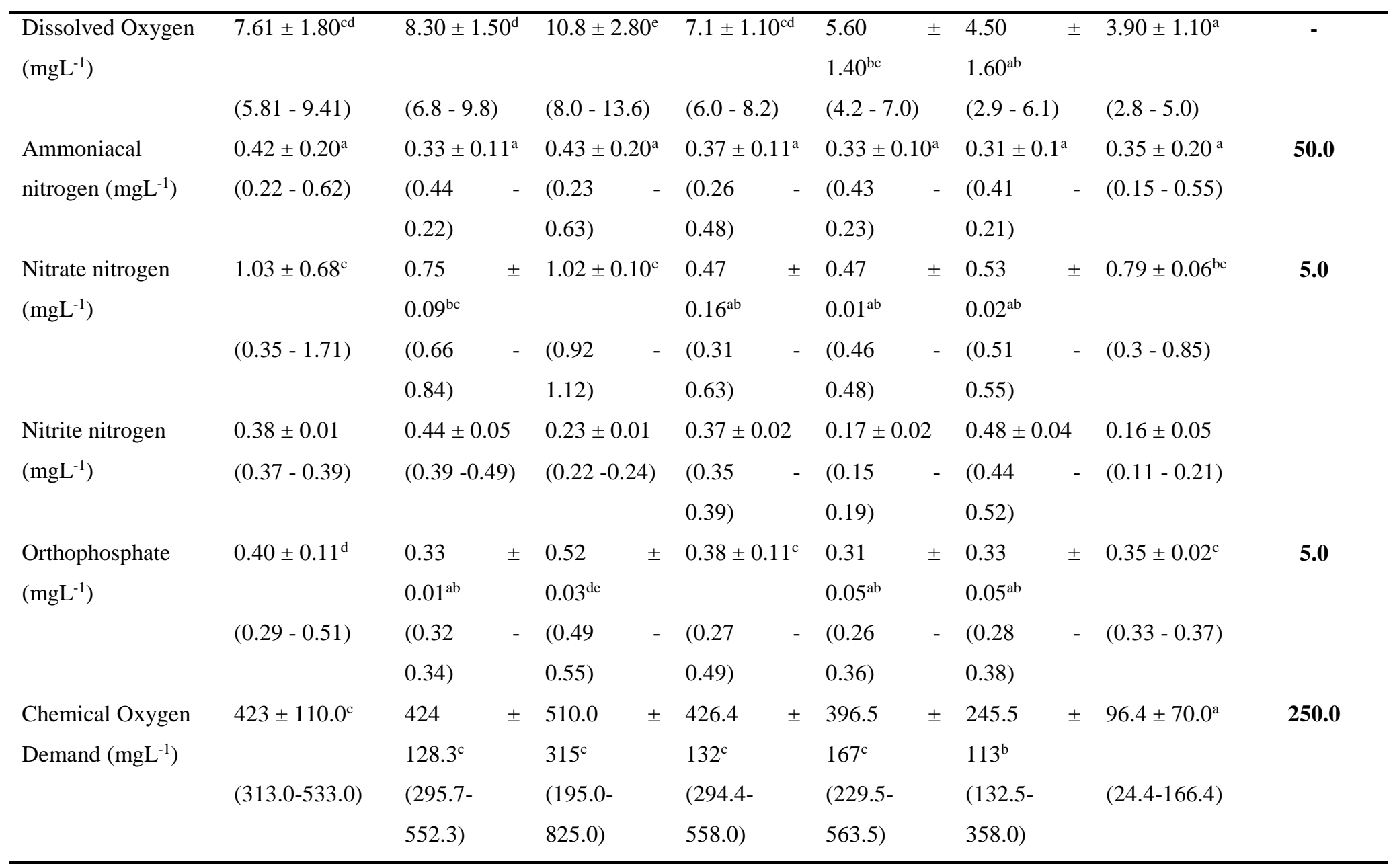




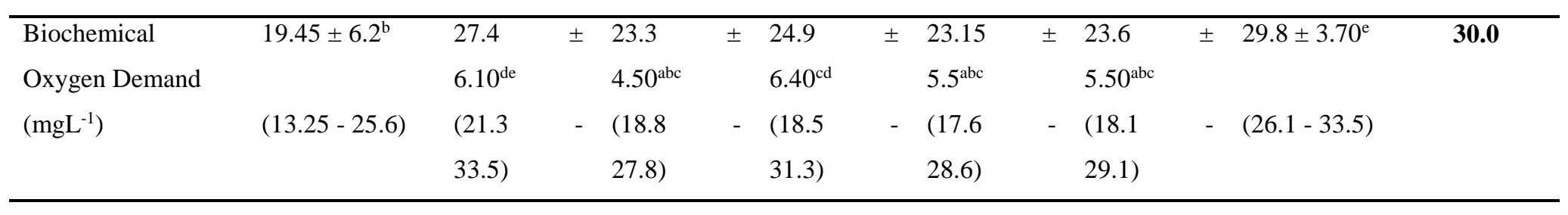

Variation of the physicochemical factors of overlying water between the study sites of Negombo estuary and reference site $(\mathrm{n}=24)$.

Results are presented as mean \pm standard error of the mean ranges for sampling events. For each parameter, means indicated by different superscript letters $(a, b, c)$ are significantly different from each other (ANOVA, Tukey’s test, $p<0.05$ ). 


\section{Relation to Physico-chemical Parameters}

Figure 2: Spatial variations of average a) DO $\left.\left(\mathrm{mgL}^{-1}\right), b\right) \mathrm{pH}$, c) EC $\left(\mathrm{mScm} \mathrm{c}^{-1}\right)$, d) Salinity (ppt),

e) $\left.B O D\left(m g L^{-1}\right), f\right) C O D\left(m g L^{-1}\right)$ and $\left.g\right)$ Nutrients $\left(m g L^{-1}\right)$ concentrations in Negombo estuary.

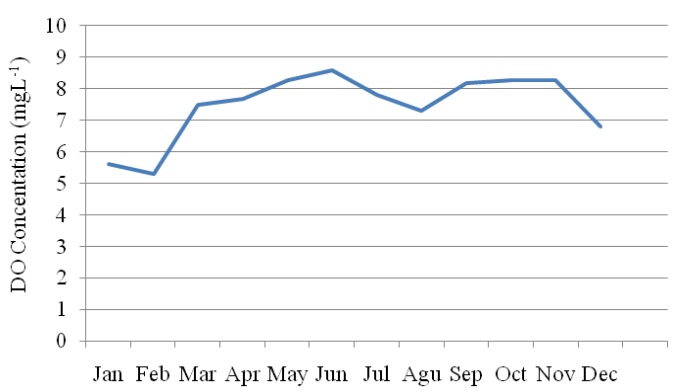

a

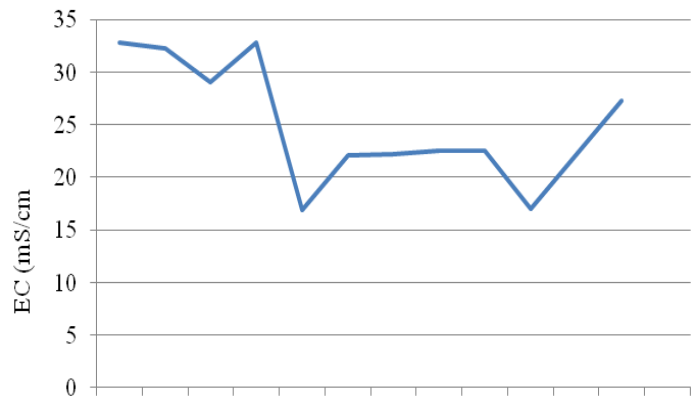

Jan Feb Mar Apr May Jun Jul Agu Sep Oct Nov Dec

C

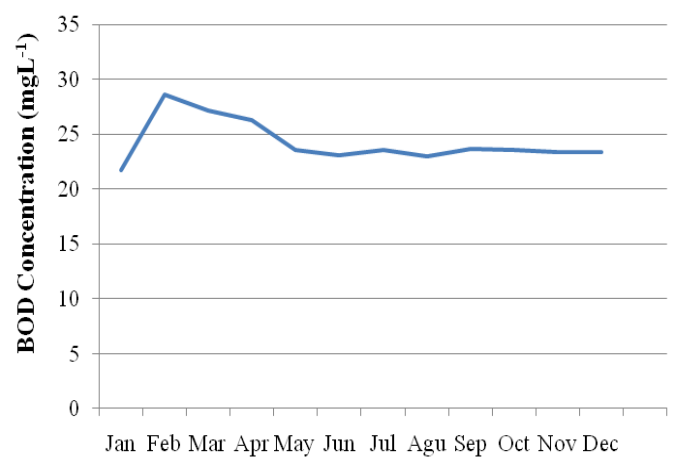

e

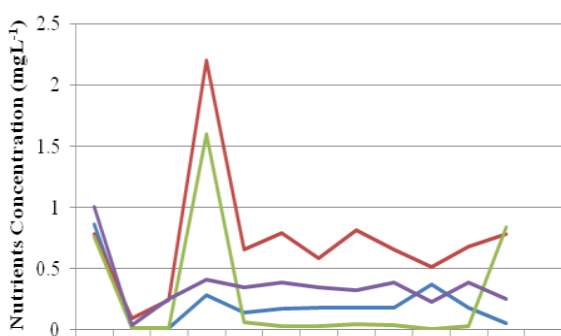

Jan Feb Mar Apr May Jun Jul Agu Sep Oct Nov Dec

-Ammonia -Nitrate - Nitrite - Phosphate

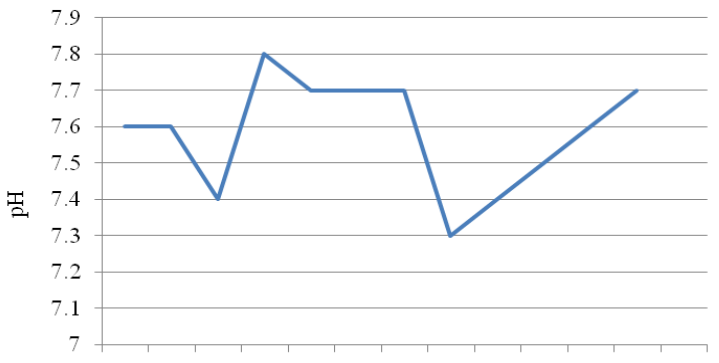

Jan Feb Mar Apr May Jun Jul Agu Sep Oct Nov Dec

b

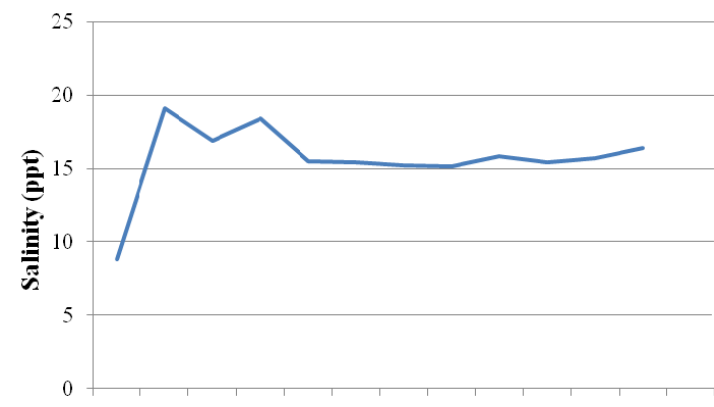

Jan Feb Mar Apr May Jun Jul Agu Sep Oct Nov Dec

d

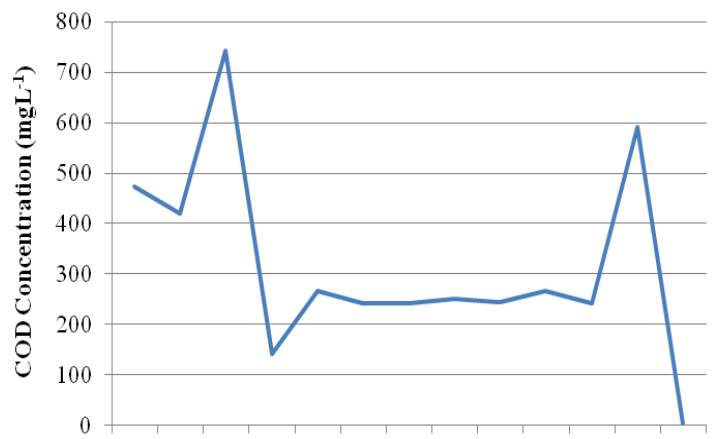

Jan Feb Mar Apr May Jun Jul Agu Sep Oct Nov Dec

f

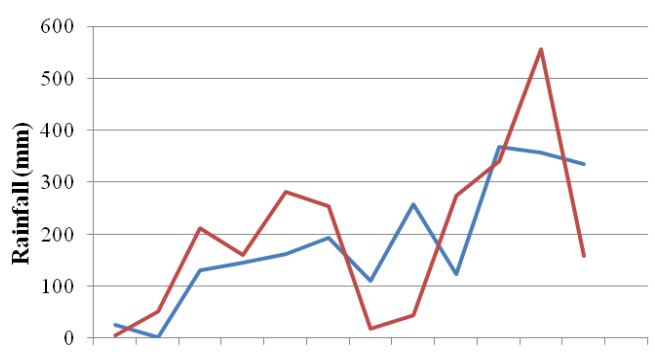

Jan Feb Mar Apr May Jun Jul Agu Sep Oct Nov Dec

$-2014 \quad-2015$

Rainfall 
The dendrogram of the cluster analysis (Figure 3, based on Euclidean Distance) suggested the presence of three major clusters. Sites 1 to 4 formulated the first cluster, while sites 5 and 6 formed the second cluster at a Euclidean distance of 6.56. On the other hand, sites 7 resulted the third cluster, which separated at a Euclidean distance of 13.24 from the other two clusters (Figure 3). The results of the Analysis of Similarities (ANOSIM) also confirmed the statistical significance of above three clusters $(p<0.05$, Global R 0.751) interns of overall physico- chemical parameters of estuarine water among the sampling sites. Multi - dimensional scaling which resulted MDS plot with satisfactory 2D stress value (0.01) further verified the above mentioned clustering status of sampling sites interns of the physico chemical parameters of water, over the period of sampling period (Figure 3).

In the first cluster, the physico - chemical parameters in the Northern region at the channel segment of the estuary together are at $25 \%$ similarity level. Further, the two sites 3 and 6 were more or less similar to each other ( $p$ > 0.05 , One-way ANOSIM). In the second cluster sites 7 within the Dandugam oya of the estuary clustered together at similarity level where again the physico chemical parameters between these sites were more or less similar to each other ( $p>0.05$, One - way ANOSIM).

In the present study, for the year 2017, the Pearson correlations coefficients were calculated to obtain associations between physico - chemical properties of water variables in rainfall and are presented in Table 3. The correlation coefficient measures the degree of association that exists between two variables, one taken as dependent variable. Table 3 represents the correlation matrixes for the eleven water quality parameters for monsoon seasons.

$\mathrm{pH}$ values range from $7.20 \pm 0.22$ to $8.30 \pm 0.36$, which shows that estuarine water $\mathrm{pH}$ is near to neutral at most of the time, with periods of slightly alkalinity. These values showed neither significant seasonal variations during the sampling period nor any association with most of the water quality parameters in monsoon seasons. According to the Table 3, rainfall showed a weakly positive correlation with the Salinity and DOES ( $p$ $>0.05)$. Higher rainfall increases the oxygen solubility in water. The concentration of EC in surface water showed a positively significant 
correlation with Salinity, BOD, Nitrate and COD levels in water ( $\mathrm{p}<0.01)$. According to the mean COD value, it was noted that there is a heavy precipitation in the morning with the commencement of the monsoonal rain. The Organic pollutants entrained with the storm water have increased the COD values. Soluble reactive Orthophosphorus was significantly higher in the short rainy season (ANOVA, $\mathrm{p}<0.05$ ). The Orthophosphorus levels of the water in the middle part of the estuary are low indicating that the phosphorus was in the suspended matter would have settled within the estuary. Phosphorus levels are high at the mouth and it may due to the releasing process of sediment bind Phosphorus due to anoxic condition of the bottom. In contrast, an increase in Orthophosphorus was observed during the rainy periods. Seasonal variations of the water quality observed in Negombo estuary were mainly due to the anthropogenic inputs to the estuary and rainfall variations. 


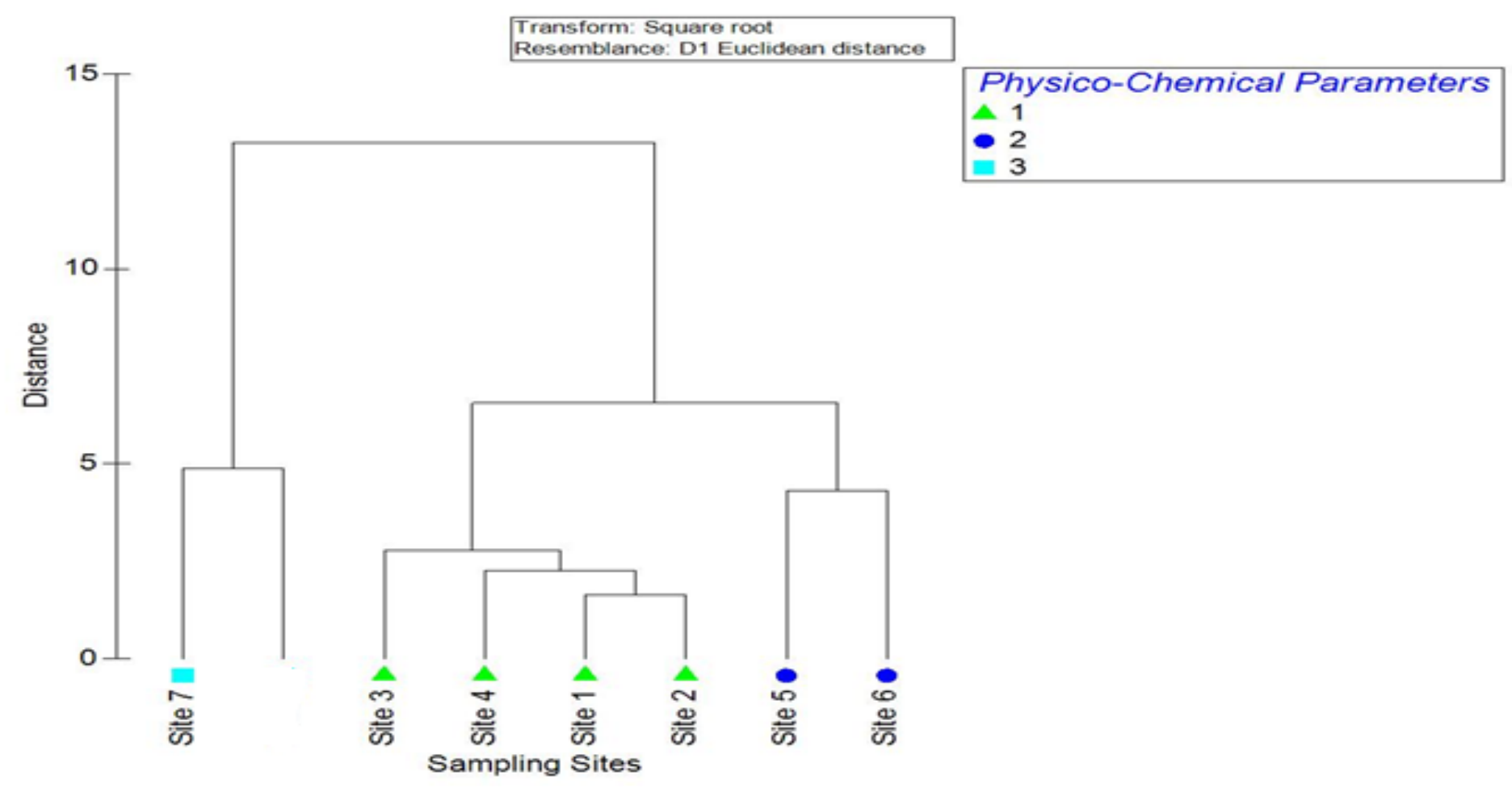


Table 3: Pearson correlation matrix for the relationships between physicochemical parameters in Negombo estuary

$\begin{array}{llllllll}\text { Rainfall pH } & \text { EC } & \text { Salinity } & \text { DO } & \text { BOD } & \text { Nitrate } & \text { Ammonia } & \text { Phosphate } \\ \text { COD }\end{array}$

\begin{tabular}{lllllllllll}
\hline Rainfall & 1 & & & & & & & & & \\
$\mathrm{pH}$ & -.052 & 1 & & & & & & & \\
$\mathrm{EC}$ & -.140 & .039 & 1 & & & & & & \\
Salinity & .016 & -.075 & $.456^{* *}$ & 1 & & & & & \\
DO & $.159^{*}$ & $.179^{*}$ & .048 & $.366^{* *}$ & 1 & & & & \\
BOD & -.056 & .088 & $.234^{*}$ & .068 & -.202 & 1 & & & \\
Nitrate & .049 & .050 & $.258^{*}$ & .047 & -.145 & .056 & 1 & & \\
Ammonia & -.139 & .064 & -.013 & -.011 & -.111 & -.195 & .136 & 1 & & \\
Phosphate & -.160 & -.049 & -.146 & -.192 & .035 & $-.245^{* *}$ & $.219^{* *}$ & $.502^{* *}$ & 1 & \\
COD & .008 & -.161 & $.367^{* *}$ & $.196^{*}$ & -.010 & $.162^{*}$ & .087 & -.144 & -.020 & 1 \\
\hline
\end{tabular}

${ }^{*}$ Correlation is significant at 0.05 levels $(2$ - tailed).

${ }^{* *}$ Correlation is significant at 0.01 levels $(2$ - tailed). 


\section{Discussion}

The high population density, high concentration of industries and fishery related activities have combined to make heavy demands on Negombo estuary. Increasing human populations and economic development have contributed to the worsening in water quality, including periodic accumulation of metals from brackish water estuary (Zhang et al., 2015). Water quality of Negombo estuary is influenced by several inland watersheds (Dadugam Oya and Hamilton canal) and the sea. Dandugam Oya carries a large amount of silt and organic matter from the associated lands along its way to the estuary (Silva, 1996). Further, the influence of the sea is minimum at this site; hence chances are highest for the silt and organic matter to settle on the bottom with time. Suspended materials sink and accumulate on the bottom forming sediments characterized by fine particles and high organic matter content deposits in the estuary (Tagliapietra et al. (2004). Due to the high amount of organic matter, microbial population should also be very high in these sites. Negombo estuarine water is polluted by faecal pollution, visual pollution, nutrient enrichment (eutrophication), organic and heavy metal pollution and oil pollution (Silva 1996). The estuary is susceptible to chemical pollution due to ongoing development activities of Negombo and Katunayake areas (CEA, 1994). Silva (1996) has reviewed available information on water quality of several water bodies, including Negombo estuary enabling direct comparison between different water quality studies. The quality of water for fish should not allow accumulation of pollutants especially heavy metals in fish to such extent that they are potentially harmful (Alabaster and Lloyed, 1982). However, monitoring the status of metal pollution in Negombo estuary would be important to human health because of the fishery of the estuary (Indrajith et al., 2008). According to the finding of this study, the surface water temperature varied between $29.50 \pm 0.40^{\circ} \mathrm{C}$ to $30.7 \pm 0.19^{\circ} \mathrm{C}$ at sites 1 to 7 showed a similar trend during the study period.

The significant difference could be attributed to the fact that around the East and South where there is more mangrove vegetation cover compared to the North region, which is sparsely vegetated. Govindasamy et al. (2000) stated that surface water temperature is influenced by the intensity of solar 


\section{Relation to Physico-chemical Parameters}

radiation, insulations, evaporation, daily weather condition, freshwater influx, cooling and mix up adjoining waters. Devendra (2003), in a review of the results of various water quality studies in Negombo estuary, observed a uniform pattern in the seasonal variation of physico - chemical characteristics of the estuary. Surface water temperature is one of the important factors affecting aquatic environments for two reasons.

Water salinity is changed due to several factors namely evaporation, precipitation and freshwater runoff from the rivers or canals (Garrison, 2004). Salinity levels in estuaries can rise on hot sunny days, when evaporation increases. The Negombo estuary shows temporal and spatial variations in salinity changes, maximum during February, April and minimum during May, June and November, highly influenced with rainfall, in the study area. Seasonal salinity changes in Negombo estuary is positively correlated with seasonal rainfall of the catchment area of the Attanagalu Oya (Silva 1996). Even though there are low salinity values here compared to the other sites, the freshwater runoff from the Atthanagalu Oya, salinity is to act as a limiting factor in the distribution of living organisms (Silva, 1996) and changes in the brackish water habitats such as estuaries are due to the influx of freshwater from runoff caused by rainfall, evaporation and tidal volume. On the other hand, salinity can be reduced by large amount of rain, which increases the flow of freshwater into the estuary from canals. It varied between $2.0 \mathrm{ppt}$ during the wet season and $31.0 \mathrm{ppt}$ at the end of the main dry season. During the intermediate rainy season (January and July), a pronounced salinity gradient developed in the estuary, varying from $20-30$ ppt at the mouth to $<5-10 \mathrm{ppt}$ at the downstream of the estuary (Devendra, 2003). The main flow is from the river to the estuary and after mixing with the saline water, it moves towards the sea via the inlet of Negombo estuary. It appears that the estuary has a positive balance of water, but there is a shortfall in inputs because of evaporation in the marsh during January March. Spring tides are also relatively high during that period, resulting in an enhanced flow of sea water into the estuary. As a result, a low salinity has been recorded in Dandugam Oya but higher salinity in sea mouth is due to the increased tidal sea water incursion. However, the distribution of salinity is very wide and high salinities have been recorded at both ends of the canal compared to the middle portion. The salinity change within the acceptable 
range for coastal water bodies is influenced by both sea water and freshwater (Silva, 1996). Salinity levels greatly influence the organisms that inhabit in the area. Salinity levels at the study areas were within the threshold limits of water quality standards of CEA (2007).

According to the insitu analysis, the average Electrical Conductivity (EC) value of the estuarine waters has been from $17.8-26.7 \mathrm{mScm}^{-1}$. EC is a useful indicator of the mineralization in a water sample (Jain et al., 2005). Increase in EC values of Negombo estuary during January and April months were because of high water current recorded in these months. The temporal variations in conductivity could be attributed to water level fluctuation in the estuary. However, the highest EC was observed in site 01, because open water of Sea mouth area is influenced by the strong water currents from the sea and from the estuary.

The result revealed that there were no significant differences in $\mathrm{pH}$ among the eight sampling sites, which were investigated. The high $\mathrm{pH}$ values during this period is recorded at the North region than South region and it may be due to decaying of the decomposing sediments, dumping of domestic solid wastes and discharge of industrial wastes to the North site. The recorded mean $\mathrm{pH}$ values in all the sampling sites were within acceptable permissible limits of CEA (2007). The $\mathrm{pH}$ range within the study area was found out to be suitable for fisheries. According to Abowei (2010), $\mathrm{pH}$ higher than 7.0, but lower than 8.5 are ideal for biological productivity, but $\mathrm{pH}<4$ is detrimental to aquatic life. The monthly $\mathrm{pH}$ values in this study is indicated slightly alkaline, except for rainy season. The $\mathrm{pH}$ of water is very important because it affects the solubility and availability of nutrients and their utilization by aquatic organisms. The discharge of various types of waste materials from industries into the water bodies also raises the concentration of metals. Rainwater, which has a slightly acidic $\mathrm{pH}$, as well as dilution effect, could be responsible for the decreased $\mathrm{pH}$ values in the months of May/June and October/November. According to the fluctuations in $\mathrm{pH}$ values during different seasons of the year is attributed to factors like removal of $\mathrm{CO}_{2}$ by photosynthesis through bicarbonate degradation, dilution of seawater by freshwater influx, low primary productivity, reduction of salinity, temperature and decomposition of organic materials (Odu, 1996). 
In this study, the low dissolved oxygen values found in site 7 could be attributed to wastewater received from Ekala industrial zone, discharging organic wastewater, which increased organic matter and decomposed dissolve organic matter. Higher DO concentrations are observed during the months of May/June and October/November, which is the rainy season and the water is coldest. During the monsoon season, DO is higher due to the effect of higher wind velocity, rainfall and the resultant freshwater mixing that is mainly attributed to seasonal variations of DO (Mitra et al., 2010). The DO values were significantly different among the sampling sites.

In this study, nutrient concentration mainly varied in the season due to tidal conditions and freshwater flow from land sources. Municipal sewage, fertilizer runoff and industrial wastewater carried in by riverine flow usually contain high levels of nitrogen and phosphorus that can stimulate eutrophication. During the field sampling, it was observed that the water colour at site 4 is greenish may be due to eutrophication. Tourist sector development activities and squatter settlements in the shoreline too contribute significantly to the nutrient budget (CCD, 2005). The highest nitrate concentration levels were recorded during the rainy season, due to increased drainage water from the mixing of effluents with estuarine water. Amarasiri (2007) stated that the large amount of nitrogenous fertilizers has contributed to increased levels of nitrate in water in many countries. The sampling sites 1 and 3 situated at North region recorded relatively high levels of nitrate nitrogen concentration which could be due to the effluents from the raw fish processing factories available in this area. It is a heavily polluted site where the untreated effluents are discharged from nearby piggeries, shrimp farms and poultry farms. It is noted that the dissolved nitrate nitrogen concentration of this site was relatively high probably due to the effluents from the raw fish processing factories established nearby sea mouth in the main fish landing site. The highest nitrate nitrogen concentration recorded at this site may be due to the above reasons. Although a reason for this cannot be indicated, it can be assumed that the dredging has released the nitrates, phosphates and nitrites that had been trapped in the sediments over the years resulting in the increases, while the point sources also keep on adding these substances to the estuary. 
Highest amount of ammoniacal nitrogen concentration was recorded at site 03 compared with other sites, because of the effects of solid wastes dumped from residential areas, discharge of sewage effluents, discharge of fish wastes and anthropogenic activities. This could be due to dumping of domestic wastes by the surrounding houses also. It also might be attributed to raw human sewage and animal faecal matter being discharged into the water. According to several studies, Ammoniacal nitrogen concentrations in all the sites showed low levels during the whole period of investigation, which were below the maximum permissible limits for the discharge of industrial wastewater standards of CEA (2007).

Nitrite nitrogen levels were high in sites 2 and 6. High concentration of orthophosphates observed during rainy season might possibly be due to intrusion of upwelling seawater into the estuary, which increased the levels of orthophosphate. The orthophosphate and nitrate nitrogen levels in the estuary could be attributed to oxidation of organic matter, human and animal wastes, laundry, cleaning, fertilizer runoff and industrial discharges from urbanization areas. The nutrient loads are therefore predominantly coming from fertilizer runoff carried into the estuary by the Dandugam Oya (CCD, 2005). The orthophosphate levels have gone up in all reaches of the estuary, indicating that the overall input into the estuary is on the rise. The source of high levels of Phosphates is attributed to activities associated with the lower reaches of the estuary. However, the total nitrogen in the upper reaches was extremely high, due to mild flushing taking place in the upper reaches and storage of nitrogen in the form of particulate matter (CCD, 2005).

Biochemical Oxygen Demand (BOD) in Dandugam Oya is due to industrial effluents and high amount of organic matter from different pollution sources. Over the years, there have been no drastic changes in BOD levels, with a trend of high BOD at the downstream reaches than the upstream reaches of the estuary (CCD, 2005). The BOD values of different areas suggest organic pollution, with the water unsuitable for all beneficial uses. The high BOD levels are attributed mostly to low flushing rates in the estuary (CCD, 2005). High values of BOD were recorded during February to April and it was due to the microbial utilization of oxygen levels deplete creating low levels of 
DO which is harmful for aquatic organisms. Further, the influence of the sea is minimum at this site, and silt and organic matter settle on the bottom with time. Due to the high amount of organic matter, microbial population could be very high in this site.

Higher COD values were recorded in sites 1, 2, 3, 4 and 5 may be due to the presence of higher organic matter concentration discharged from untreated industrial effluents into the estuary by some of the factories in these areas, in addition to the discharge of municipal wastewater (untreated and detergent carrying wastewater) and other domestic wastes dumped into the estuary. Sea mouth is situated by the north of the estuary and is continuously influenced by the strong water currents from the sea and from the estuary. These water currents shear the bottom and suspend the less heavy silt, clay and organic matter particles to be carried away leaving the heavier sand particles on the bottom. Of the three remaining study sites, Duwa, Pitipana and Munnakkaraya occur within the channel segment of the estuary. These sites are relatively highly disturbed by anthropogenic activities and are not directly influenced by the sea or the freshwater drainage. The monthly variation of high COD values were recorded during the March and November months and low levels were recorded in April and December. During low flows (non - monsoonal periods), the COD load is estimated at $850 \mathrm{~kg} /$ day while the BOD load was $280 \mathrm{~kg} /$ day. The COD to BOD ratio suggest that the major portion of the organic matter is biodegradable and hence lesser in toxicity. These loads seem to be made up of urban and industrial runoff during the dry season, more than $50 \%$ of the load is from industrial flows (CCD, 2005). Owing to the inherent features, it is therefore surprising to find significant variations of the physico - chemical parameters in overlying water of these study sites. Low COD may be due to decreased mixing of industrial and domestic waste, land drainage into the estuary and decreased biological activities. COD is an indicator of organic pollution, which is caused by the inflow of domestic, livestock and industrial waste that contains elevated levels of organic pollutants (Ayati, 2003).

The levels of similarity at which observations are merged, form the dendrogram that provides a visual summary of the clustering process, presenting a picture of the clusters and their proximity with a dramatic 
reduction in dimensionality of the original data. The correlated variables are grouped together and separated from other variables with low or no correlation. Cluster 1 represents a similarity level grouping together the sampling sites $1,2,3$ and 4 which are significantly influenced by the Northern region. The association of these sites in the same Cluster is due to their similar characteristics in terms of the correlation coefficients distance of their physico - chemical parameters. The high similarity level of the sites of Northern region is probably related to the similar pollution sources such as urban wastewater, domestic solid waste and industrial runoff discharges from the surrounding towns. These pollutants have caused higher COD and BOD levels. Cluster 2 is associated with the inter cluster sampling sites 5 and 6 including western and eastern regions with true estuarine features, Cluster 3 is associated with the sampling site 7 which is influenced by the freshwater. The mixing of the estuarine water with the freshwater in this site causes reduction in salinity and normal physico - chemical parameters and nutrients content by decreasing the similarity levels from the reference site. The urban wastewater discharges have a strong influence on the parameters under investigation in Negombo estuary. The association of these sites in the same Cluster is due to their similar characteristics in terms of the correlation coefficients and distance of their physico - chemical parameters.

In conclusion, results of the present study revealed that the physico chemical variables such as temperature, salinity, electrical conductivity, $\mathrm{pH}$, dissolved oxygen, ammoniacal nitrogen, nitrite nitrogen and orthophosphrous values of all the sampling sites were below the maximum recommended values for the discharge of industrial wastewater quality standards of (CEA, 2007). The nitrate nitrogen level was higher than the permissible threshold limits (CEA, 2007), in the sea mouth site, due to the discharge of industrial untreated effluents, domestic and municipal solid waste dumping and sewage discharge, release of burned and unburned fuel from motor boats. The Chemical Oxygen Demand levels were higher than the permissible threshold limits (CEA, 2007) in the sampling sites of Sea mouth, Duwa, Pitipana, Munnakkaraya, Dandugam Oya and Katunayake area. High COD levels are an evidence of the untreated industrial waste discharged into the Northern region. 


\section{Acknowledgements}

The Authors wish to express their sincere gratitude to the South Eastern University of Sri Lanka. They also extend their thanks to the National Aquatic Resources Research and Development Agency (NARA) for providing financial assistance to conduct the present study.

\section{References}

Abowei, J. F. N. (2010). Salinity, dissolved oxygen, pH and surface water temperature conditions in Nkoro River, Niger Delta, Nigeria. Adv. J. Food Sci. Technol., 2(1), pp. 16 - 21.

Alabaster, J. S., and Lloyed, R. (1982). Water quality Criteria for freshwater fish. $2^{\text {nd }}$ Edition, FAO, by Butterworth Sceintific. London. 361p.

Amarasiri, S. (2007). Declining Water Quality and its effect on Water Security, In: Water Resources Research in Sri Lanka, De Silva R. P. and Dayawansa N. D. K. (Ed.) Symposium proceedings of The Water Professionals' Day, Geo - Informatics Society of Sri Lanka (GISSL), pp 1 - 10.

American Public Health Association (APHA). (2012). Standard methods for the Examination of Water and Wastewater $22^{\text {nd }}$ edition, Published by American Water Works Association Washington, DC - 20005.

Ayati, B. (2003). Investigation of sanitary and industrial wastewater effects on Anzali Reserved Wetland (Final report). MAB - UNESCO, Tarbiat Modarres University, Iran. 53p.

Central Environmental Authority (CEA). (2007). Ambient water quality standards for inland waters Sri Lanka. Central Environmental Authority, Sri Lanka. 
Central Environmental Authority (CEA). (1994). Muthurajawela marsh and Negombo Lagoon. Wetland Conservation Plan, Central Environmental Authority, Sri Lanka.

Costal Conservation Department, (CCD). (2005). Special Area Management Plan for Negombo Lagoon Coast First Edition, Colombo. 70 p.

Day, J.W.A.S. Hall, W. M. Kemp \& A. Yanez - Arancibia. (1989). Estuarine ecology. John Wiley, New York.

Devendra, A. (2003). Hydrodynamics of Muthurajawela Marsh \& Negombo Lagoon Coastal Wetland Ecosystem, Project EMBioC - Effective Management for Biodiversity Conservation in Sri Lankan Coastal Wetlands, Final report A - VII, University of Moratuwa, Darwin Institute and University of Portsmouth.

Garrison, T. (2004). "Essential of Oceanography". 3rd Ed. Thomson Learning 511 Forest Lodge Road, Pacific Grove, CA 93950, USA, $113 \mathrm{p}$.

Govindasamy, C., L. Kannan and J. Azariah. (2000). Seasonal variation in physico - chemical properties and primary production in the coastal water biotopes of Coromandel coast. Indian Journal of Environmental Biology 21: pp. 1 - 7.

Hettiarachchi, S. S. L. and Samarawickrama, S. P., (2003). Towards Improved Environmental Management of the Negombo Lagoon. COPEDEC VI. Journal of the institution of engineers, XXXIV(1), pp. $43-55$.

Indrajith, H. A. P. Pathirane, K. A. S and Pathirane, A. (2008). Heavy metal levels in two food fish species from Negombo estuary, Sri Lanka; Relationships with the body size. Sri Lanka. J. Aquat. S., (13): pp. $63-81$. 
Jain, C. K., Singhal, D. C. Sharma, U. K. (2005). Metal pollution assessment of sediment and water in the river Hindon, India. Environ. Monit. Assess. 105, pp. 193 - 207.

McDonough, C. J., and Wenner, C. A. (2003). Growth, recruitment and abundance of juvenile Mugil cephalus in South Carolina estuaries. Fisheries Bulletin 101: pp. 343 - 357.

Mitra, A., Banerjee, K., Ghosh, R., and Ray, S. K. (2010). Bioaccumulation pattern of heavy metals in the shrimps of the lower stretch of the River Ganga. Mesopotamian Journal of Marine Science, 25(2): pp. 114.

Mushatq, B., Raina, R., Yaseen, T., Wanganeo, A., and Yousuf, A. R. (2013). Variations in the physicochemical properties of Dal Lake, Srinagar, Kashmir. African Journal of Environment Science and Technology Vol.7: pp. 624 - 633.

Narayanan, M., and Vinodhini, R. (2008) . Bioaccumulation of heavy metals in organs of fresh water fish Cyprinus carpio (Common Carp). International Journal of Environmental Science and Technology, 2(5), pp. 179 - 182.

Odu, C. T. I. (1996). Pollution and rehabilitation of wetland soils of Nigeria. Monograph. No 2. J. Soil Sci. Soc. Nig. pp. 107 - 113.

Silva, E. I. (1996). Water Quality of Sri Lanka. A review of twelve water bodies institute of fundamental studies, Kandy, Sri Lanka.

Tagliapietra, D., A. Rismondo and Frangipane, G. 2004. Coastal Lagoons: Spatial Patterns of Benthic Assemblages and Bioindication, 1CNRISMAR (National Research Council, Institute for Marine Science), Riva Sette Martiri, IOC Workshop Report. pp. 195 - 234.

Wijeyaratne, M. J. S. and Costa, H. H. (1987). Fishery, Seasonal Abundance and Mortality of Grey mullet (Mugilidae) in Negombo Lagoon, Sri Lanka. Jour. of Applied Ichthyology 3: pp. 115 -118. 
Zhang L., Z. Shi, J. P. Zhang, Z. Jiang, F. Wang and X. Huang. (2015). Spatial and seasonal characteristics of dissolved heavy metals in the east and west Guangdong coastal waters, South China, Mar. Pollut. Bull. 95, 419 - 426. 